\title{
Methane, Nitrous Oxide and Ammonia Emissions from Livestock Farming in the Red River Delta, Vietnam: An Inventory and Projection for 2000-2030
}

\author{
An Ha Truong ${ }^{1,2}$, Minh Thuy Kim ${ }^{1}$, Thi Thu Nguyen ${ }^{1}$, Ngoc Tung Nguyen ${ }^{1}$ and \\ Quang Trung Nguyen ${ }^{1, *}$ \\ 1 Center for Research and Technology Transfer, Vietnam Academy of Science and Technology, \\ 18-Hoang Quoc Viet, Cau Giay, 100000 Hanoi, Vietnam; truonganha87@gmail.com (A.H.T.); \\ thuythuy1107@gmail.com (M.T.K.); thu.nguyen27393@gmail.com (T.T.N.); \\ tungnguyen.vast@gmail.com (N.T.N.) \\ 2 University of Science and Technology of Hanoi, Vietnam Academy of Science and Technology, \\ 18-Hoang Quoc Viet, Cau Giay, 100000 Hanoi, Vietnam \\ * Correspondence: trungnq@ctctt.vast.vn; Tel.: +84-243-756-8422
}

Received: 29 September 2018; Accepted: 18 October 2018; Published: 22 October 2018

\begin{abstract}
Livestock farming is a major source of greenhouse gas and ammonia emissions. In this study, we estimate methane, nitrous oxide and ammonia emission from livestock sector in the Red River Delta region from 2000 to 2015 and provide a projection to 2030 using IPCC 2006 methodologies with the integration of local emission factors and provincial statistic livestock database. Methane, nitrous oxide and ammonia emissions from livestock farming in the Red River Delta in 2030 are estimated at $132 \mathrm{kt}, 8.3 \mathrm{kt}$ and $34.2 \mathrm{kt}$, respectively. Total global warming potential is estimated at $5.9 \mathrm{MtCO}_{2 \mathrm{eq}}$ in 2030 and accounts for $33 \%$ of projected greenhouse gas emissions from livestock in Vietnam. Pig farming is responsible for half of both greenhouse gases and ammonia emissions in the Red River Delta region. Cattle is another major livestock responsible for greenhouse gas emissions and poultry is one that is responsible for ammonia emissions. Hanoi contributes for the largest emissions in the region in 2015 but will be surpassed by other provinces in Vietnam by 2030.
\end{abstract}

Keywords: emission inventory; livestock; greenhouse gases; air pollutant

\section{Introduction}

Economic growth in Vietnam has shifted food consumption patterns to incorporate more livestock products (meat, dairy products, and eggs) [1]. With the growing demand for livestock products, livestock farming is expanding in Vietnam and is among the fastest growing agricultural production subsectors in Vietnam [1]. In 2015, livestock accounted for $28 \%$ of value added from the agriculture sector. The development and intensification of this subsector has led to an increase in the total animal population during the past decade. In 2016, Vietnam had 29 million pigs, 5.5 million cattle, 2.5 million buffalos, and 361 million poultry [2]. The largest population increases compared to 2005 have been in poultry (increased by 65\% with 142 million head added), followed by pigs (increased by $8 \%$ with 2 million head added); while numbers of cattle and buffalo have fluctuated slightly.

The development and intensification of livestock farming helps to ensure national food security and boosts economic growth. However, this sector is also a significant contributor to environmental pollution in general and air pollution in particular. Livestock farming contributes significantly to global greenhouse gas (GHG) emissions [3] by releasing methane $\left(\mathrm{CH}_{4}\right)$ and nitrous oxide $\left(\mathrm{N}_{2} \mathrm{O}\right)$, as well as air pollutants, mostly ammonia $\left(\mathrm{NH}_{3}\right)$, into the atmosphere. Livestock farming is the largest emissions source of $\mathrm{NH}_{3}$ [4-6], which plays a major role in eutrophication and acidification [7]. The Food and 
Agriculture Organization (FAO) has estimated that $18 \%$ of global GHG emissions originate from the livestock sector.

Vietnam is listed among the 20 countries with the highest GHG emissions in the UNFCCC and FAOSTAT databases [8]. Emissions from livestock farming account for approximately $20 \%$ of greenhouse gas emissions from agricultural activities in Vietnam according to the National GHG emissions inventory for 2010 [9]. Emissions from enteric digestion are responsible for half of all livestock emissions, with the other half originating from manure management, one of the fastest-growing sources of GHG emissions in Vietnam during 1994-2010 [5]. An inventory of $\mathrm{CH}_{4}$ emissions from livestock in Asia in 2000 [10] showed that poultry emitted the largest amounts of $\mathrm{CH}_{4}$ in Vietnam, followed by cattle, buffalo, and pigs. $\mathrm{A} \mathrm{CH}_{4}$ and $\mathrm{N}_{2} \mathrm{O}$ emissions inventory for South, Southeast, and East Asia was recently conducted [11] using emissions inventory methodologies from the International Panel on Climate Change (IPCC) 1997 Guidelines for National Emission Inventory, and ranked Vietnam in 6th place for $\mathrm{NH}_{3}$ emissions and 7th place for $\mathrm{CH}_{4}$ and $\mathrm{N}_{2} \mathrm{O}$ emissions among the 23 countries studied. An estimate of air pollutants and GHGs over Asia aggregated Vietnam within the Southeast Asia region [12]. To the best of our knowledge, no emissions inventory has been conducted for $\mathrm{CH}_{4}$ and $\mathrm{N}_{2} \mathrm{O}$ in Vietnam using IPCC 2006 methodologies. Previous studies estimating livestock farming emissions in Vietnam have been conducted at the provincial scale or for one type of pollutant (such as GHG or air pollutant). Examples of such studies include estimates of $\mathrm{CH}_{4}$ emissions from cattle in Daklak province [13], $\mathrm{CH}_{4}$ emissions from cattle in Quang Ngai province, with mitigation scenarios [14], and GHG and pollutants from livestock farming within a ward of Hung Yen province [15].

It is important to develop a historical inventory and projections of future livestock GHG and air pollutants to improve our understanding of the evolution of emissions and their associated impact on air quality. In this study, we focused on the Red River Delta (RRD) region, which is among the largest livestock farming centers in Vietnam. This region contained 8726 livestock farms in 2016, accounting for $42 \%$ of all livestock farms in the country [2]. RRD contains the largest number of pigs and poultry, with populations of 7.4 million and 93.7 million head, respectively (account for $26 \%$ of country's total). This inventory attempts to quantify emissions of $\mathrm{CH}_{4}, \mathrm{~N}_{2} \mathrm{O}$, and $\mathrm{NH}_{3}$ produced by livestock farming, in RRD from 2000 to 2030 at a 5-years resolution using the IPCC 2006 Guidelines for National Emission Inventory [16] and regional or country-specific emission factors wherever applicable. Its results are designed to provide input to more comprehensive studies about regional air quality, for example using an air dispersion model and the Greenhouse Gases-Air Pollution Interactions and Synergies (GAINS) model.

\section{Materials and Methods}

\subsection{Emission Inventory Methodology}

We conducted an emissions inventory for livestock farming for the sources and pollutant species listed in Table 1. We applied emissions inventory methodologies from the IPCC Guidelines for the National Emission Inventory [16]. In general, we applied Tier 1 methods, such that activity data were multiplied by relevant emission factors. Country-specific emission factors were used (Tier 2 method) wherever applicable. The general equation for estimating livestock emission is Equation (1) [17].

$$
E_{j}=\sum_{T} N_{T} \times E F_{T, j}
$$

where $E_{j}$ is the emission from animal type $T$ and pollutant $j ; N_{T}$ is the number of animal of type $T, E F_{T, j}$ is the emission factor for animal type $T$ for pollutant $j$. 
Equation (2) from IPCC 2006 Guidelines was used to estimate direct $\mathrm{N}_{2} \mathrm{O}$ emissions from manure management.

$$
E_{N 2 O}=\left[\sum_{S}\left[\sum_{T}\left(N_{T} \times N e x_{T} \times M S_{T, S}\right)\right] \times E F_{S}\right] \times \frac{44}{28}
$$

where $N_{T}$ is number of animal type $T, N e x_{T}$ is the annual average Nitrogen excretion per head of animal type $T$. Nex $x_{T}$ is calculated using Equation (3), where $N_{\text {rate } T}$ is the default Nitrogen excretion rate; TAM is the typical animal mass for animal type $T$. Both values are provided in the IPCC 2006 Guidelines. Value of $N e x_{T}$ for animals in Asia are listed in Table 2. $M S_{T, S}$ is the fraction of total annual nitrogen excretion for each animal of type $T$ in manure management system $S . M S_{T, S}$ is provided in Table 3. $E F_{S}$ is default emission factor for direct $\mathrm{N}_{2} \mathrm{O}$ emission from manure management system $S$ (Table 3). $44 / 28$ is the conversion of $\mathrm{N}_{2} \mathrm{O}-\mathrm{N}$ emissions to $\mathrm{N}_{2} \mathrm{O}$ emissions.

$$
\mathrm{Nex}_{T}=\mathrm{N}_{\text {rate }} \times \mathrm{TAM} / 1000 \times 365
$$

Table 1. Activities and pollutant species included in the inventory.

\begin{tabular}{cccc}
\hline Source/Pollutant & $\mathbf{C H}_{4}$ & $\mathbf{N}_{2} \mathbf{O}$ & $\mathbf{N H}_{3}$ \\
\hline Enteric fermentation & $\checkmark$ & & \\
Manure management & $\checkmark$ & $\checkmark$ & $\checkmark$ \\
\hline
\end{tabular}

\begin{tabular}{|c|c|c|c|}
\hline Animal & $N_{\text {rate } T}(\mathrm{kgN} / 1000 \mathrm{~kg}$ Animal Mass/Day) [16] & TAM (kg/Animal) [16] & $\mathrm{Nex}_{T}(\mathrm{kgN} / \mathrm{Head} / \mathrm{yr})[16]$ \\
\hline Dairy cattle & 0.47 & 350 & 60.043 \\
\hline Other cattle & 0.34 & 319 & 39.588 \\
\hline Pigs & 0.42 & 28 & 4.292 \\
\hline Poultry & 0.82 & 1.8 & 0.539 \\
\hline Goats & 1.37 & 30 & 15.002 \\
\hline Horses & 0.46 & 238 & 39.960 \\
\hline Buffalo & 0.32 & 380 & 44.384 \\
\hline
\end{tabular}

Table 2. Nitrogen (N) excretion per animal type $\left(\mathrm{kgN}_{\mathrm{gead}}{ }^{-1} \mathrm{yr}^{-1}\right)$.

$N_{\text {rateT }}$, default $\mathrm{N}$ excretion rate; TAM, typical animal mass for animal of type $T$; $N e x_{T}$, annual average $\mathrm{N}$ excretion per head of animal of type $T$.

Table 3. Fraction of total annual $\mathrm{N}$ excretion for each animal type and emission factors by manure

\begin{tabular}{|c|c|c|c|c|c|c|c|c|}
\hline \multirow{2}{*}{$\begin{array}{l}\text { Manure Management } \\
\text { System }\end{array}$} & \multicolumn{7}{|c|}{$\begin{array}{c}\text { Fraction of Total Annual N Excretion (kg N Excreted) by Manure } \\
\text { Management System }\end{array}$} & \multirow{2}{*}{$\begin{array}{c}\text { Emission Factor } \\
\mathrm{kg} \mathrm{N2O-N/kg} \mathrm{N} \\
\text { Excreted }\end{array}$} \\
\hline & Dairy Cattle & Other Cattle & Pig & Horse & Goat & Buffalo & Poultry & \\
\hline Daily spread & 0.29 & 0.02 & - & - & - & 0.04 & 0.55 & 0 \\
\hline Solid storage & - & - & 0.15 & - & - & - & - & 0.005 \\
\hline Dry lot & 0.07 & 0.48 & - & - & - & 0.46 & - & 0.02 \\
\hline Pit storage & - & - & - & - & - & - & - & 0.002 \\
\hline Anaerobic digester & 0.02 & - & 0.30 & - & - & - & - & 0 \\
\hline Composting static pile & - & - & 0.40 & - & - & - & - & 0.006 \\
\hline Poultry manure with litter & - & - & - & - & - & - & 0.45 & 0.001 \\
\hline
\end{tabular}
management system.

\subsection{Data}

The RRD region consists of 11 provinces and two cities, including Hanoi, the capital of Vietnam. In our inventory, historical activity data from 2000 to 2015 was acquired at the provincial level and summed to obtain regional data. Projected activities were obtained from approved provincial, regional, and national agricultural development plans. 
Historical data on provincial livestock numbers were obtained from the Statistical Yearbook of each province and from the Vietnam Statistical Yearbook $[18,19]$. More detailed data (e.g., numbers of dairy cattle and laying hens) were obtained from the Department of Livestock Production, Ministry of Agriculture and Rural Development, and are publicly accessible [20]. Livestock is classified into the following groups: Dairy cattle, other cattle, pigs, poultry, horses, and goats. Data on livestock number by province is provided in Table S1, Supplementary Materials.

Projected livestock numbers for 2020 were obtained from the Provincial Agriculture Development Plan for each province. Projections for 2030 were not available for all provinces examined in this study; therefore, we distributed the projected livestock populations for Vietnam in 2030 [21] into these provinces using the proportion of each type of animal of each province over the national total in 2020. Projections for 2025 take the average of 2020 and 2030 values. Historical and projected livestock populations are presented in Table 4.

Table 4. Livestock population data used in this emissions inventory.

\begin{tabular}{cccccccc}
\hline Animal $\mathbf{( 1 \mathbf { 1 } ^ { \mathbf { 3 } } \text { Head) }}$ & $\mathbf{2 0 0 0}$ & $\mathbf{2 0 0 5}$ & $\mathbf{2 0 1 0}$ & $\mathbf{2 0 1 5}$ & $\mathbf{2 0 2 0}$ & $\mathbf{2 0 2 5}$ & $\mathbf{2 0 3 0}$ \\
\hline Dairy Cattle & 13.5 & 20.0 & 19.3 & 48.3 & 45.3 & 63.7 & 77.5 \\
Other cattle & 489.4 & 689.9 & 604.0 & 445.4 & 754.1 & 757.7 & 871.4 \\
Poultry & 54,742 & 59,597 & 76,394 & 90,829 & 97,686 & 109,352 & 124,153 \\
Horses & 1.5 & 1.3 & 1.8 & 0.9 & 1.0 & 1.0 & 0.9 \\
Goat & 10.5 & 10.5 & 75.6 & 79.1 & 96.8 & 112.1 & 129.6 \\
Buffalo & 278.1 & 209.1 & 168.7 & 130.4 & 130.2 & 108.4 & 108.7 \\
Pig & 5688 & 7796 & 7301 & 7061 & 9326 & 9906 & 10,476 \\
\hline
\end{tabular}

Distributions of $\mathrm{N}$ excretion for each animal type managed under different manure management systems are provided in Table 3. We estimated the proportion of manure by type of management system for the pig and poultry industries using results from previous studies [22-24]. We used default values from the IPCC 2006 Guidelines for cattle, buffalo, and other animals.

\subsection{Emission Factors}

A summary of the $\mathrm{CH}_{4}$ and $\mathrm{NH}_{3}$ emission factors used in this study is provided in Table 5. We used regional emission factors for $\mathrm{CH}_{4}$ emission fromenteric fermentation from previous studies for dairy and beef cattle [25,26] and buffalo [15]. We used the IPCC 2006 default values for all other animals. We used the IPCC 2006 Guidelines for $\mathrm{N}_{2} \mathrm{O}$, in which emission factors were specified for manure management systems (Table 3). We used an adjusted European $\mathrm{NH}_{3}$ emission factors [11], which were also used in a previous study [15] for Vietnam.

Table 5. Methane $\left(\mathrm{CH}_{4}\right)$ and ammonia $\left(\mathrm{NH}_{3}\right)$ emission factors.

\begin{tabular}{|c|c|c|c|c|c|c|c|c|}
\hline & & Dairy Cattle & Other Cattle & Pig & Horse & Goat & Buffalo & Poultry \\
\hline \multirow{3}{*}{$\begin{array}{l}\text { Enteric fermentation } \\
\mathrm{CH}_{4}\left(\mathrm{~kg} / \text { head }^{-1} \mathrm{yr}^{-1}\right)\end{array}$} & & & & & & & & \\
\hline & used in this study & $94.5^{\mathrm{a}}$ & $41^{\mathrm{a}}$ & $1^{\mathrm{c}}$ & $18^{\mathrm{c}}$ & $5^{c}$ & $82.3^{\mathrm{b}}$ & - \\
\hline & IPCC $2006^{c}$ & 68 & 47 & 1 & 18 & 5 & 55 & - \\
\hline \multicolumn{9}{|l|}{ Manure Management } \\
\hline $\mathrm{CH}_{4}\left(\mathrm{~kg} / \mathrm{head}^{-1} \mathrm{yr}^{-1}\right)$ & & $26^{c}$ & $1^{c}$ & $6^{c}$ & $1.64^{\mathrm{c}}$ & $0.17^{\mathrm{c}}$ & $2^{c}$ & $0.02^{c}$ \\
\hline $\mathrm{NH}_{3}\left(\mathrm{~kg} / \mathrm{head}^{-1} \mathrm{yr}^{-1}\right)$ & & $5.6^{\mathrm{b}}$ & $3^{b}$ & $1.5^{\mathrm{b}}$ & $7^{b}$ & $1.1^{\mathrm{b}}$ & $3.4^{b}$ & $0.12^{b}$ \\
\hline
\end{tabular}

\section{Results}

\subsection{Estimated Total Emissions}

Figure 1 shows the estimated $\mathrm{CH}_{4}, \mathrm{~N}_{2} \mathrm{O}$ and $\mathrm{NH}_{3}$ emissions from livestock farming in RRD. Total $\mathrm{CH}_{4}$ emissions in 2015 were $87 \mathrm{kt}$ (Figure 1a), or $2.4 \mathrm{MtCO}_{2}$ equivalent $\left(\mathrm{CO}_{2 \mathrm{eq}}\right)$ as determined using the global warming potential (GWP) for 100-year time horizon from IPCC Fifth Assessment Report [27]. 
Given the current agricultural development plan, the total amount of $\mathrm{CH}_{4}$ emissions for RRD in 2030 was estimated at $132 \mathrm{kt}$, or $3.7 \mathrm{Mt} \mathrm{CO}_{2 \mathrm{eq}}$. Decreases in $\mathrm{CH}_{4}$ emissions in 2010 and 2015 were due to decreases in numbers of other cattle and buffalo in those years. Although the buffalo population continued to decrease in the subsequent years, increases in the numbers of other animals kept $\mathrm{CH}_{4}$ emissions on an upward trend from 2020 onward. Enteric fermentation and manure management contributed equally to total $\mathrm{CH}_{4}$ emissions, which were estimated at 63 and $69 \mathrm{kt}$, respectively, for

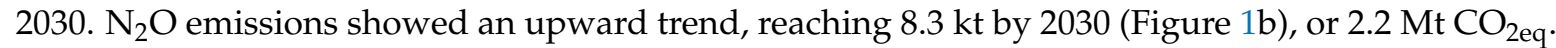
Although $\mathrm{N}_{2} \mathrm{O}$ emissions were 16-fold lower than those of $\mathrm{CH}_{4}$, higher GWP limited the global warming impacts of $\mathrm{N}_{2} \mathrm{O}$ to 1.6 times lower than those of $\mathrm{CH}_{4}$.

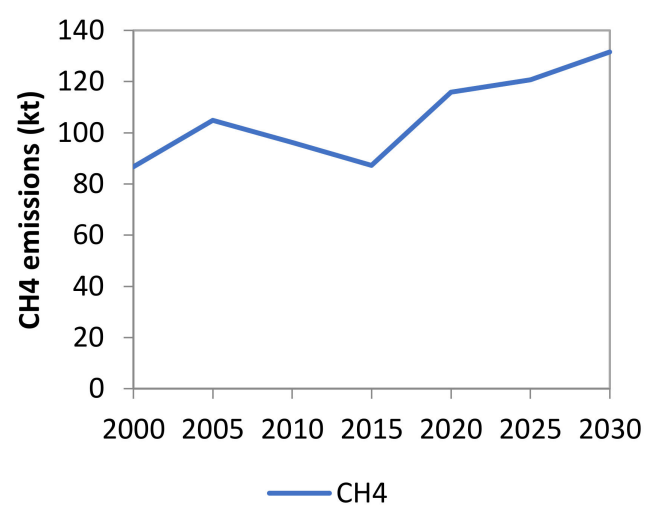

(a)

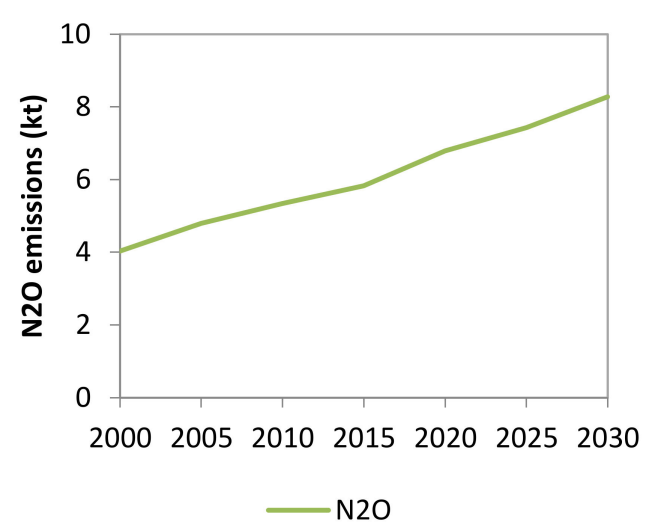

(b)

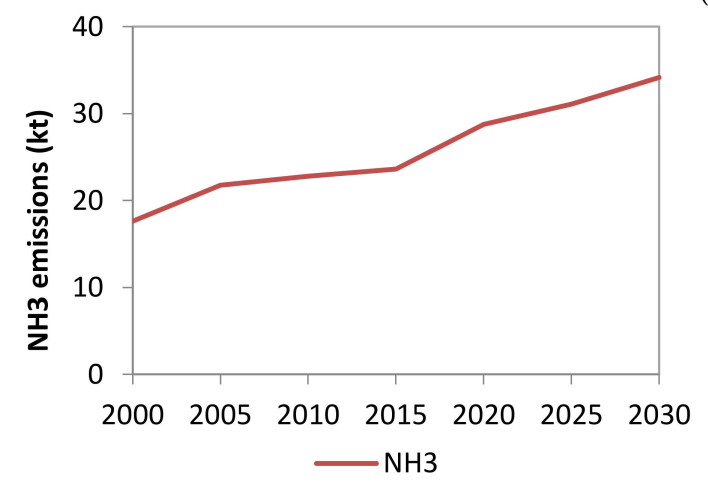

(c)

Figure 1. Total $\mathrm{CH}_{4}(\mathbf{a}), \mathrm{N}_{2} \mathrm{O}(\mathbf{b})$ and $\mathrm{NH}_{3}$ (c) emissions from livestock farming in the RRD region.

The total GHG emissions from livestock from our estimation for RRD region in 2015 is $4.0 \mathrm{MtCO}_{2 \mathrm{eq}}$. GHG emissions projection for 2020 and 2030 are 5.0 and $5.9 \mathrm{MtCO}_{2 \mathrm{eq}}$, respectively. Our estimations indicates that RRD region accounts for about one-third of Vietnam's GHG emissions from livestock farming according to the national GHG inventory [9]. This result reflects the fact that RRD is the largest livestock farming center in Vietnam. Compare with a previous estimate [28], as summarized in Reference [1], our estimation results in much higher GHG emissions. Total GHG emissions from livestock in RRD is estimated at $2.1 \mathrm{MtCO}_{2 \mathrm{eq}}$ in 2012 in the study of Reference [28] while our estimation for 2010 is $4.1 \mathrm{MtCO}_{2 \mathrm{eq}}$.

$\mathrm{NH}_{3}$ emissions increased over time as the animal population expanded during the past decade, and are projected to further increase until 2030 (Figure 1c). By 2030, total $\mathrm{NH}_{3}$ emissions from livestock in RRD are expected to reach $34 \mathrm{kt}$.

\subsection{Emissions by Animal Type}

$\mathrm{CH}_{4}$ emissions from enteric fermentation and manure management were of the same order of magnitude. However, the contributions differed by animal type in these emissions categories. Cattle 
contributed the largest proportion of $\mathrm{CH}_{4}$ emissions from enteric digestion (Figure 2a). Modifying diet is one of the mitigation option for methane emissions from enteric fermentation [29]. Several studies have explored the potential for emissions reduction by changing cattle diet at a local scale $[13,25,26]$. The National Plan for GHG emissions reduction in the agricultural sector by 2020 [30] has proposed two measures to reduce enteric fermentation emissions: (i) changing the feeding proportion in $30 \%$ of total amount of animal feed to reduce $0.91 \mathrm{MtCO}_{2 \mathrm{eq}}(3.73 \% \mathrm{GHG}$ emissions in livestock production projected for 2020) and (ii) supply Molasses Urea Block for 192,000 dairy cattle for a reduction of 0.37 $\mathrm{MtCO}_{2 \mathrm{eq}}(1.51 \%$ GHG emissions in livestock production projected for 2020). However, the practice of implementing those mitigation measures nation-wide is not yet documented.

$\mathrm{CH}_{4}$ emissions from manure management are produced mainly from pig farming (Figure $2 \mathrm{~b}$ ). Pig husbandry emits $50 \mathrm{kt}$ of methane in 2015, accounts for $57 \%$ total methane emission. The dominance of pig farming in $\mathrm{CH}_{4}$ emission suggests that more effort should be made to effectively mitigate emissions in this sector, as RRD has the highest pig farming density in Vietnam. The most common method of emissions mitigation in Vietnam is the production of biogas from pig manure due to subsidization of anaerobic digester construction by the government [31].

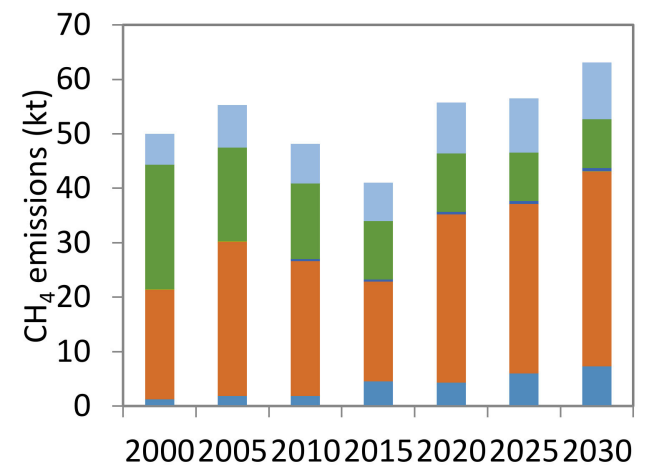

(a)

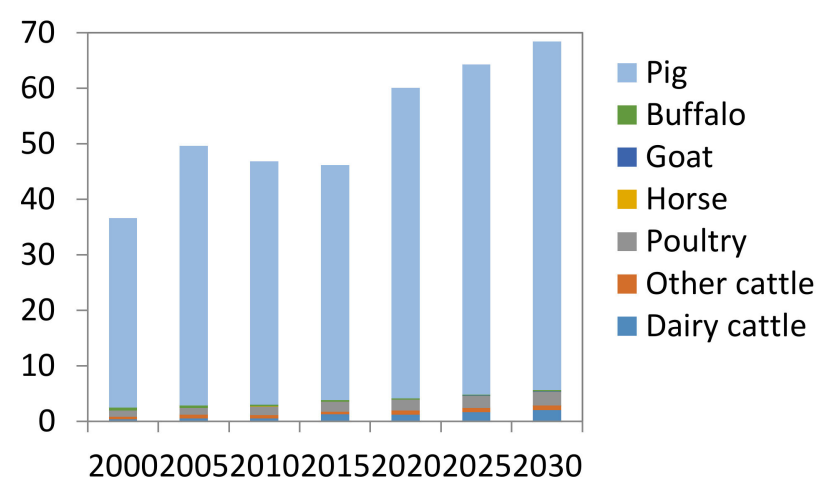

(b)

Figure 2. $\mathrm{CH}_{4}$ emissions from enteric fermentation (a) and manure management (b).

Poultry and pig farming are responsible for about $90 \%$ of $\mathrm{N}_{2} \mathrm{O}$ (Figure 3 ) and $\mathrm{NH}_{3}$ emissions (Figure 4). Poultry accounted for largest share of $\mathrm{N}_{2} \mathrm{O}$ emissions $(60 \%)$ followed by pigs $(26 \%)$. The farming of these animals contributed equally to $\mathrm{NH}_{3}$ emissions. Although chicken manure is a preferred source of organic fertilizer [1], the remaining uncollected poultry manure apparently has a considerable impact. GHG emissions from poultry husbandry accounted for $27 \%$ of total GHG emissions from livestock farming in 2015.

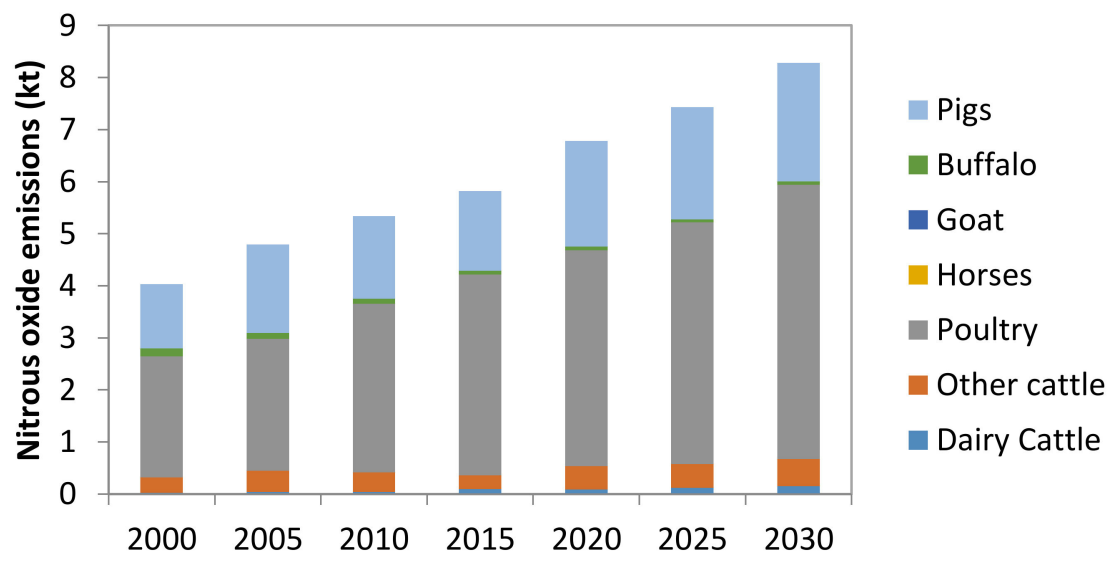

Figure 3. Nitrous oxide $\left(\mathrm{N}_{2} \mathrm{O}\right)$ emissions by animal type. 


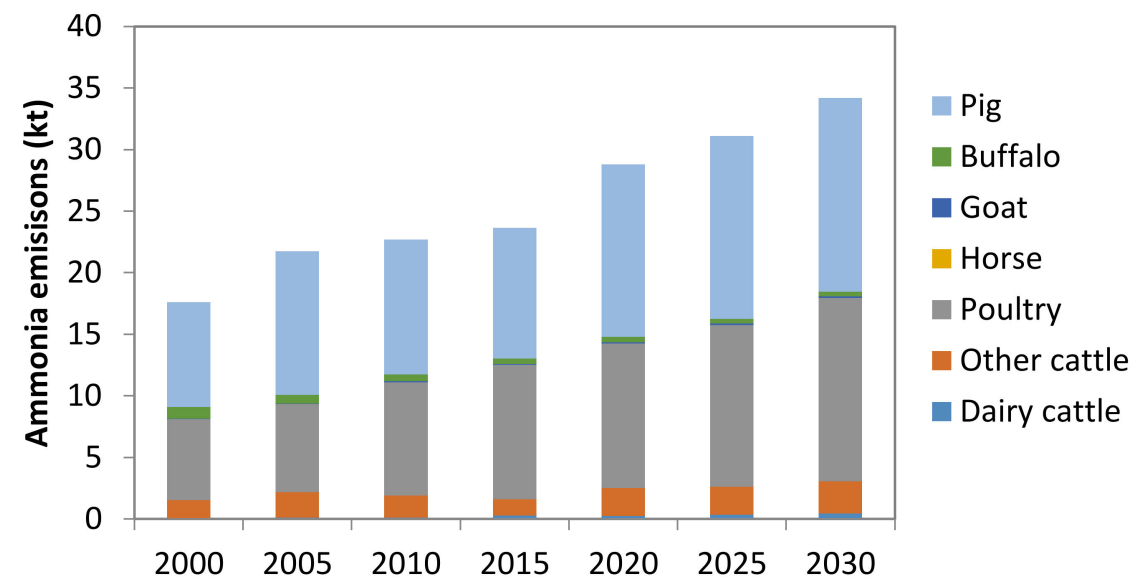

Figure 4. Ammonia $\left(\mathrm{NH}_{3}\right)$ emissions by type of animal.

\subsection{Emissions by Provinces}

Figure 5 presents methane, nitrous oxide and ammonia emissions by provinces in the Red River Delta in 2015 and projection for 2030. In 2015, Hanoi is the dominant city for emissions (Figure 5a) with $21 \mathrm{kt}$ of methane, $1 \mathrm{kt}$ of nitrous oxide and $5.5 \mathrm{kt}$ of ammonia (Tables A1-A3). However, Quang Ninh becomes the highest emission province in the RRD by 2030, followed closely by Hanoi, Vinh Phuc and Thai Binh (Figure 5b, Tables A1-A3). This projection reflects that livestock farming will be developed more in other provinces rather than in the capital city.

$\mathrm{CH} 4, \mathrm{~N} 2 \mathrm{O}$ and $\mathrm{NH} 3$ emission from livestocks in Red River Delta in 2030 by provinces

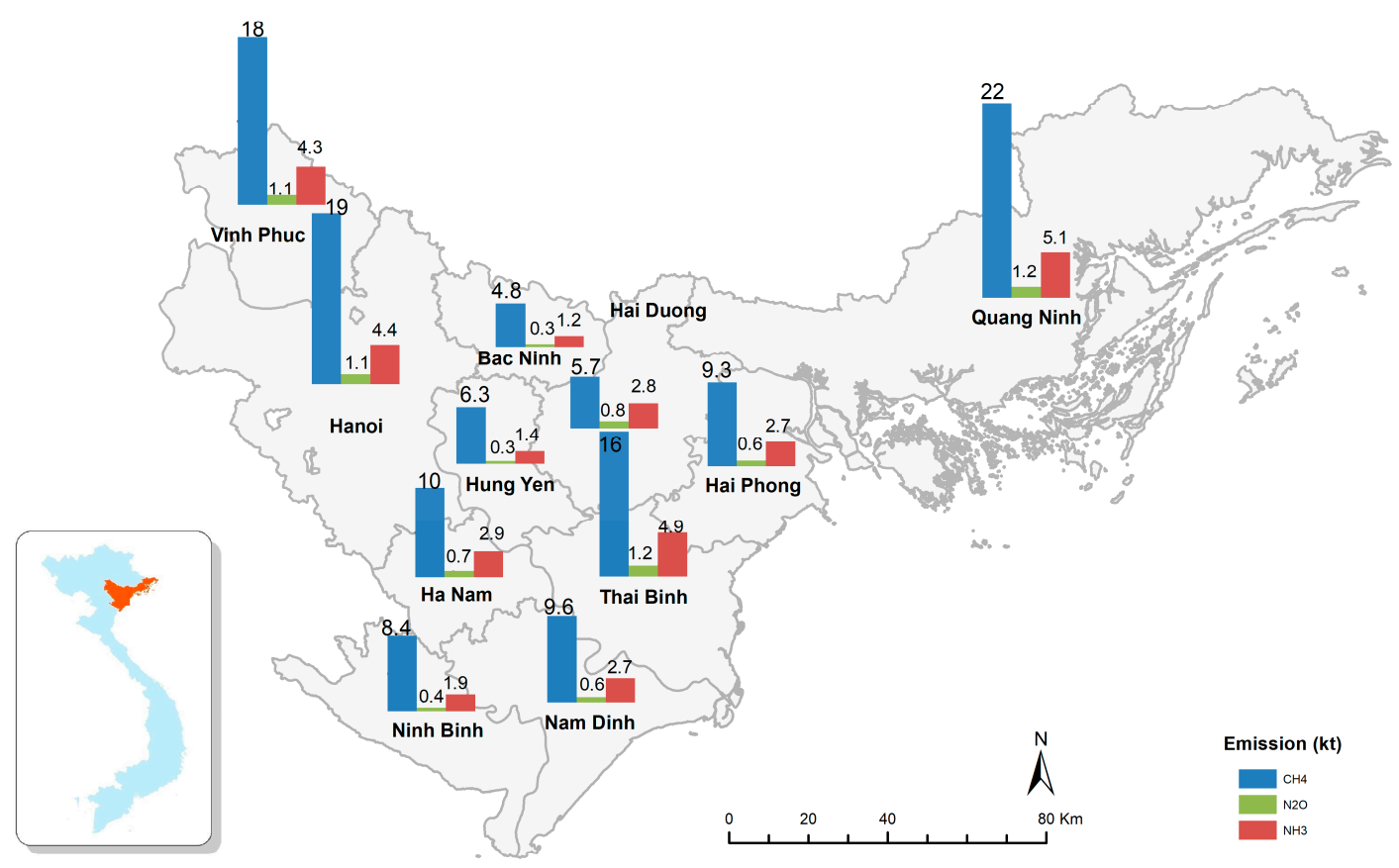

(a)

Figure 5. Cont. 
CH4, N2O and NH3 emissions from livestocks in Red River Delta in 2015 by provinces

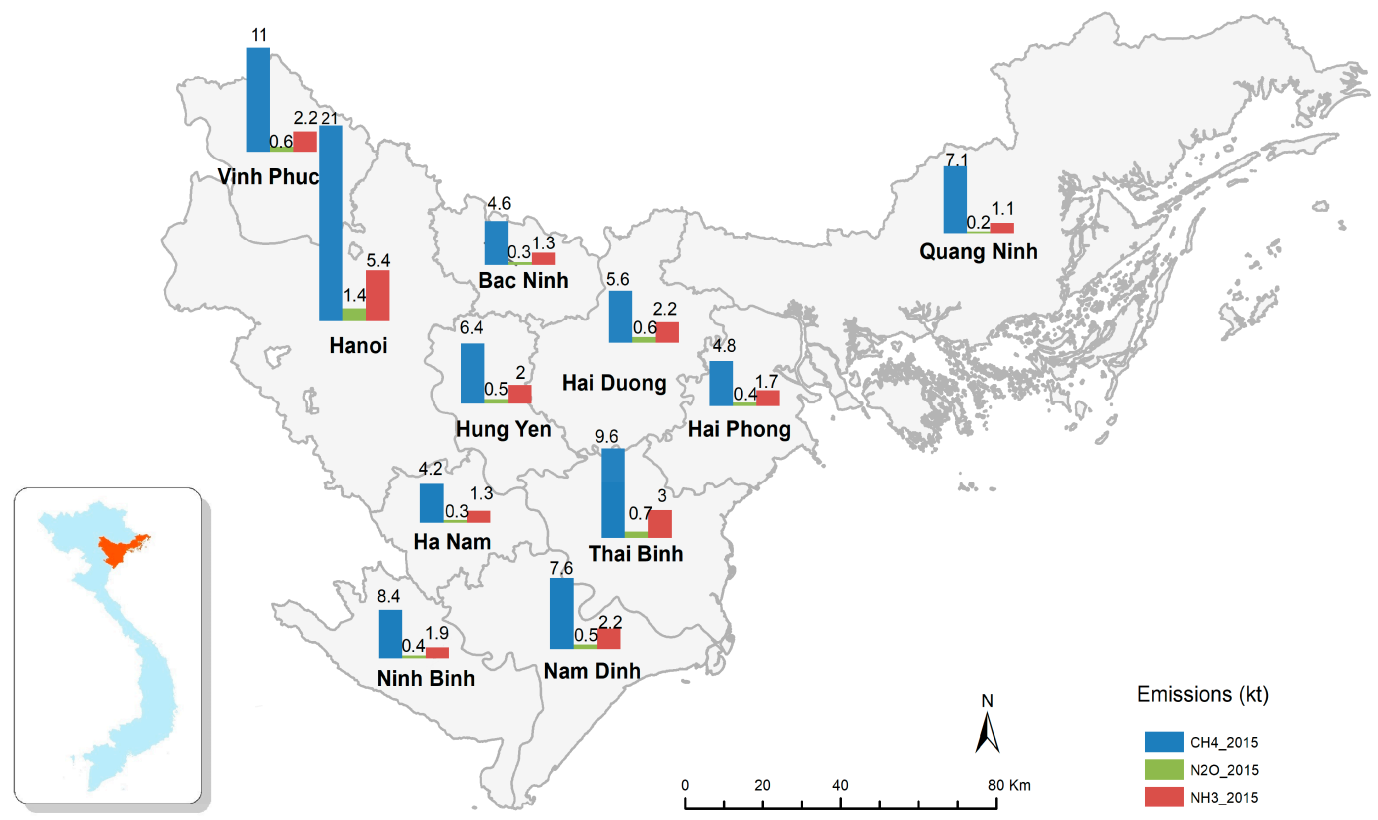

(b)

Figure 5. Emissions from livestock by provinces in 2015 (a) and projection for 2030 (b).

\section{Discussion}

Emission factor is a very important element to the accuracy of the estimations in emission inventory. Default methane emission factors for enteric fermentation in IPCC 2006 Guidelines for Asia is $68 \mathrm{~kg}$ head ${ }^{-1} \mathrm{yr}^{-1}$ for dairy cattle and $47 \mathrm{~kg} \mathrm{head}^{-1} \mathrm{yr}^{-1}$ for other cattle. We used emission factors from studies of References [25,26], which were derived from the RUMINANT model (Tier 3 methodology). These emission factors are higher for dairy cattle and lower for other cattle compared to the default values in IPCC 2006 (see Table A4, Appendix A). These emission factor discrepancies were mainly due to higher milk yields from dairy cattle and lower weight in beef cattle in the studied area. Another study [10] used IPCC 1997 default emission factors, which are lower than IPCC 2006 values for both dairy and non-dairy cattle.

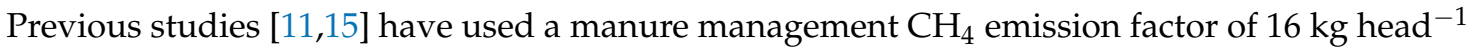
year $^{-1}$ for dairy cattle in a temperate climate region with annual average temperature ranging from 15 to $25{ }^{\circ} \mathrm{C}$. However, the IPCC 2006 guidelines provide $\mathrm{CH}_{4}$ emission factors for temperatures classified at a finer scale. We calculated the annual average temperature for the RRD region to be approximately $25^{\circ} \mathrm{C}$ using historical data from three monitoring stations in the region. According to the IPCC 2006 guidelines, the manure management $\mathrm{CH}_{4}$ emission factor for dairy cattle is $26 \mathrm{~kg}_{\text {head }}{ }^{-1}$ year $^{-1}$, much higher than the value used in previous inventories.

The $\mathrm{N}_{2} \mathrm{O}$ emission factors used in this study are presented in Table A4, and expressed in emission per animal head per year to be able to compare with the ones used in previous studies. Some studies have used IPCC 1997 default $\mathrm{N}_{2} \mathrm{O}$ emission factors for each animal type (e.g., Reference [11]), which were calculated based on proportional regional values of manure production. Our calculation resulted in higher emission factors for all animals except horses and goats; these are "pasture animals", for which $\mathrm{N}_{2} \mathrm{O}$ emissions are not accounted for as livestock but instead for soil management. Our emission factors for dairy cattle and poultry were an order of magnitude higher than those used previously [11,15]. We used the IPCC 2006 default values for dairy and non-dairy cattle to calculate emission factors, resulting in higher values than those obtained using the IPCC 1997 guidelines due 
to the incorporation of different manure management systems and the more detailed classification systems employed in the IPCC 2006 guidelines.

Pig husbandry is the largest GHG and $\mathrm{NH}_{3}$ emitter in the RRD region, which is responsible for about half of total GHG emissions (in $\mathrm{CO}_{2} \mathrm{eq}$ ) and about $46 \% \mathrm{NH} 3$ emissions from livestock in 2015. This is an atypical situation compared to neighboring countries. In the emission inventory for South, South East and East Asia for 2000 [11], cattle was the largest emitter for $\mathrm{CH}_{4}, \mathrm{~N}_{2} \mathrm{O}$ and $\mathrm{NH}_{3}$ emissions, with a share of $56 \%, 30 \%$ and 33\% respectively. Study of Reference [32] in Indonesia has also shown cattle as the major contributor to GHG emissions in the 2005-2015 period. Our results provide a reminder that regarding agricultural sector emission mitigation, policies in the Red River Delta should not be copied from other countries.

The production of emissions from livestock farming depends on various factors including feeding practices, housing systems, and manure management systems. Detailed historical data on the feed composition for each animal type and the proportions of manure managed by different management systems are needed to obtain more accurate emissions estimates. However, these data are not yet systematically collected or well documented for emissions inventory purposes. Improving the quantity and quality of data and research related to livestock farming will help to improve emissions monitoring in this sector.

Currently, environmental protection regulations for livestock farming in Vietnam mainly focus on water quality, not air quality. There is a national technical standard for wastewater from livestock farming in Vietnam, but no specific regulations with respect to manure management and air quality. In practice, compliance with and enforcement of related environmental regulations in the livestock sector are currently weak [1]. The significant contributions to GHG and air pollutant emissions from this sector deserve more attention.

\section{Conclusions}

In this study, we estimated $\mathrm{CH}_{4}, \mathrm{~N}_{2} \mathrm{O}$, and $\mathrm{NH}_{3}$ emissions from livestock farming in the RRD, northern Vietnam from 2000 to 2015 and projected future emissions to 2030. This inventory and projection yielded emissions by animal type and by province. The results of our emissions inventory indicate that livestock farming in RRD contributes significantly to GHGs and $\mathrm{NH}_{3}$ emissions. The emissions inventory and projection showed an upward trend in $\mathrm{GHG}$ and $\mathrm{NH}_{3}$ emissions during 2000-2030. The GWP of $\mathrm{CH}_{4}$ and $\mathrm{N}_{2} \mathrm{O}$ emissions was $5.9 \mathrm{MtCO}_{2 \text { eq }}$ in 2030, representing $33 \%$ of GHG emissions from livestock nationwide. Pig farming contributed the largest proportion of GHG and $\mathrm{NH}_{3}$ emissions, at 50\%. Cattle were responsible for the second largest share of GHG emissions, whereas poultry contributed most of the remaining $\mathrm{NH}_{3}$ emissions. This study also provides the provincial emissions levels for $\mathrm{CH}_{4}, \mathrm{~N}_{2} \mathrm{O}$ and $\mathrm{NH}_{3}$. Understanding the level of emissions emitted in the RRD region and the contribution of different type of livestock as well as the spatial distribution of emissions by province is a first step to developing effective mitigation strategies for reducing GHG and $\mathrm{NH}_{3}$ emission in the RRD region. Furthermore, this inventory provides an input to implementing regional air dispersion modeling for air pollution impact assessments in the RRD region.

Supplementary Materials: The following are available online at http:/ / www.mdpi.com/2071-1050/10/10/3826/ s1, Table S1. Livestock number by provinces in Red River Delta from 2000 to 2030.

Author Contributions: Conceptualization, A.H.T. and Q.T.N.; formal analysis, A.H.T., M.T.K.; data curation, M.T.K., T.T.N.; writing—original draft preparation; A.H.T.; writing—review and editing, N.T.N. and Q.T.N.; visualization, A.H.T.; supervision, N.T.N. and Q.T.N.; funding acquisition, Q.T.N.

Funding: This research was funded by Vietnam Academy of Science and Technology, grant number VAST-QTAT01.01/17-19.

Acknowledgments: The authors would like to thank Minh Ha-Duong for his comments that greatly improved the manuscript.

Conflicts of Interest: The authors declare no conflict of interest. 


\section{Appendix A}

Table A1. $\mathrm{CH}_{4}$ emissions (kt/y) by provinces.

\begin{tabular}{cccccccc}
\hline Province & $\mathbf{2 0 0 0}$ & $\mathbf{2 0 0 5}$ & $\mathbf{2 0 1 0}$ & $\mathbf{2 0 1 5}$ & $\mathbf{2 0 2 0}$ & $\mathbf{2 0 2 5}$ & $\mathbf{2 0 3 0}$ \\
\hline Hanoi & 18.99 & 24.07 & 22.88 & 20.99 & 21.11 & 19.89 & 19.02 \\
Bac Ninh & 6.29 & 6.57 & 4.88 & 4.65 & 4.71 & 4.77 & 4.77 \\
Hung Yen & 4.71 & 6.52 & 6.72 & 6.38 & 6.54 & 6.37 & 6.32 \\
Vinh Phuc & 10.81 & 13.06 & 12.34 & 11.15 & 16.00 & 16.83 & 18.65 \\
Quang Ninh & 8.12 & 9.03 & 9.01 & 7.13 & 15.92 & 17.60 & 21.66 \\
Hai Duong & 9.01 & 9.72 & 6.08 & 5.64 & 5.61 & 5.70 & 5.70 \\
Hai Phong & 5.35 & 5.85 & 5.34 & 4.76 & 7.60 & 8.15 & 9.30 \\
Thai Binh & 8.44 & 11.13 & 11.28 & 9.57 & 15.40 & 16.20 & 18.25 \\
Ha Nam & 4.12 & 5.04 & 4.45 & 4.17 & 7.12 & 8.65 & 10.00 \\
Nam Dinh & 5.67 & 7.45 & 7.50 & 7.60 & 8.61 & 9.01 & 9.56 \\
Ninh Binh & 5.11 & 6.43 & 5.68 & 5.16 & 7.25 & 7.59 & 8.37 \\
\hline
\end{tabular}

Table A2. $\mathrm{N}_{2} \mathrm{O}$ emissions (kt/y) by provinces.

\begin{tabular}{cccccccc}
\hline Province & $\mathbf{2 0 0 0}$ & $\mathbf{2 0 0 5}$ & $\mathbf{2 0 1 0}$ & $\mathbf{2 0 1 5}$ & $\mathbf{2 0 2 0}$ & $\mathbf{2 0 2 5}$ & $\mathbf{2 0 3 0}$ \\
\hline Hanoi & 0.83 & 1.12 & 1.23 & 1.38 & 1.10 & 1.11 & 1.05 \\
Bac Ninh & 0.256 & 0.298 & 0.292 & 0.31 & 0.30 & 0.30 & 0.30 \\
Hung Yen & 0.34 & 0.44 & 0.49 & 0.51 & 0.32 & 0.27 & 0.27 \\
Vinh Phuc & 0.40 & 0.25 & 0.53 & 0.57 & 0.84 & 0.96 & 1.11 \\
Quang Ninh & 0.20 & 0.22 & 0.23 & 0.23 & 0.67 & 0.82 & 1.21 \\
Hai Duong & 0.47 & 0.57 & 0.49 & 0.58 & 0.70 & 0.80 & 0.78 \\
Hai Phong & 0.30 & 0.34 & 0.39 & 0.44 & 0.50 & 0.56 & 0.61 \\
Thai Binh & 0.47 & 0.63 & 0.66 & 0.70 & 0.96 & 1.07 & 1.22 \\
Ha Nam & 0.19 & 0.25 & 0.29 & 0.34 & 0.49 & 0.58 & 0.68 \\
Nam Dinh & 0.35 & 0.42 & 0.46 & 0.50 & 0.53 & 0.57 & 0.61 \\
Ninh Binh & 0.22 & 0.25 & 0.27 & 0.27 & 0.35 & 0.38 & 0.43 \\
\hline
\end{tabular}

Table A3. $\mathrm{NH}_{3}$ emissions (kt/y) by provinces.

\begin{tabular}{cccccccc}
\hline Province & $\mathbf{2 0 0 0}$ & $\mathbf{2 0 0 5}$ & $\mathbf{2 0 1 0}$ & $\mathbf{2 0 1 5}$ & $\mathbf{2 0 2 0}$ & $\mathbf{2 0 2 5}$ & $\mathbf{2 0 3 0}$ \\
\hline Hanoi & 3.68 & 4.97 & 5.20 & 5.45 & 4.69 & 4.60 & 4.35 \\
Bac Ninh & 1.19 & 1.35 & 1.23 & 1.28 & 1.25 & 1.24 & 1.23 \\
Hung Yen & 1.38 & 1.82 & 2.00 & 2.02 & 1.53 & 1.38 & 1.38 \\
Vinh Phuc & 1.73 & 1.45 & 2.22 & 2.23 & 3.33 & 3.71 & 4.26 \\
Quang Ninh & 0.96 & 1.10 & 1.12 & 1.08 & 3.17 & 3.84 & 5.05 \\
Hai Duong & 1.99 & 2.45 & 1.96 & 2.19 & 2.54 & 2.83 & 2.79 \\
Hai Phong & 1.32 & 1.55 & 1.63 & 1.71 & 2.20 & 2.41 & 2.70 \\
Thai Binh & 2.05 & 2.87 & 2.98 & 2.95 & 4.04 & 4.39 & 4.93 \\
Ha Nam & 0.85 & 1.12 & 1.22 & 1.34 & 2.11 & 2.50 & 2.94 \\
Nam Dinh & 1.53 & 1.94 & 2.02 & 2.20 & 2.34 & 2.51 & 2.67 \\
Ninh Binh & 0.95 & 1.14 & 1.21 & 1.18 & 1.59 & 1.70 & 1.89 \\
\hline
\end{tabular}

Table A4. Comparision of emission factors used in this study and previous studies.

\begin{tabular}{|c|c|c|c|c|c|c|c|c|c|}
\hline & \multirow[b]{2}{*}{ Source } & \multirow[b]{2}{*}{ Methodology } & \multicolumn{7}{|c|}{ Type of Animal } \\
\hline & & & $\begin{array}{l}\text { Dairy } \\
\text { Cattle }\end{array}$ & $\begin{array}{l}\text { Other } \\
\text { Cattle }\end{array}$ & Pig & Horse & Goat & Buffalo & Poultry \\
\hline \multicolumn{10}{|c|}{ Enteric fermentation } \\
\hline \multirow{4}{*}{$\begin{array}{c}\mathrm{CH}_{4} \\
\left(\mathrm{~kg} / \text { head }^{-1} \mathrm{yr}^{-1}\right)\end{array}$} & IPCC 2006 [16] & Tier 1 & 68 & 47 & 1 & 18 & 5 & 55 & - \\
\hline & [15] & Tier 2 & 50.46 & 64.15 & - & - & - & 82.3 & - \\
\hline & [25]; [26] & $\begin{array}{c}\text { Tier 3, } \\
\text { RUMINANT } \\
\text { model }\end{array}$ & 94.5 & 41 & - & - & - & - & - \\
\hline & [10] & Tier 1 & 47 & 44.9 & 1 & 18 & 5 & 53.2 & - \\
\hline
\end{tabular}


Table A4. Cont.

\begin{tabular}{|c|c|c|c|c|c|c|c|c|c|}
\hline & \multirow[b]{2}{*}{ Source } & \multirow[b]{2}{*}{ Methodology } & \multicolumn{7}{|c|}{ Type of Animal } \\
\hline & & & $\begin{array}{l}\text { Dairy } \\
\text { Cattle }\end{array}$ & $\begin{array}{l}\text { Other } \\
\text { Cattle }\end{array}$ & Pig & Horse & Goat & Buffalo & Poultry \\
\hline \multicolumn{10}{|c|}{ Manure Management } \\
\hline \multirow{2}{*}{$\begin{array}{c}\mathrm{CH}_{4} \\
\left(\mathrm{~kg} / \mathrm{head}^{-1} \mathrm{yr}^{-1}\right)\end{array}$} & $\begin{array}{c}\text { IPCC } 1997 \\
{[10,15]}\end{array}$ & Tier 1 & 16 & 1 & 4 & 1.6 & 0.18 & 2 & 0.018 \\
\hline & $\begin{array}{l}\text { IPCC } 2006 \text { temp. } \\
25^{\circ} \mathrm{C}\end{array}$ & Tier 1 & 26 & 1 & 6 & 1.64 & 0.17 & 2 & 0.02 \\
\hline \multirow{3}{*}{$\begin{array}{c}\mathrm{N}_{2} \mathrm{O} \\
\left(\mathrm{kg} / \text { head }^{-1} \mathrm{yr}^{-1}\right)\end{array}$} & {$[11,15]$} & Tier 1 & 0.29 & 0.34 & 0.18 & 0.87 & 0.17 & 0.39 & 0.0069 \\
\hline & IPCC 1997; & Tier 1 & 0.29 & 0.34 & 0.18 & 0.77 & 0.77 & 0.34 & 0.0068 \\
\hline & $\begin{array}{l}\text { Used in this } \\
\text { study }\end{array}$ & & 1.92 & 0.60 & 0.22 & 0.00 & 0.00 & 0.55 & 0.0425 \\
\hline $\begin{array}{c}\mathrm{NH}_{3} \\
\left(\mathrm{~kg} / \mathrm{head}^{-1} \mathrm{yr}^{-1}\right)\end{array}$ & [15]; [11] & & 5.6 & 3 & 1.5 & 7 & 1.1 & 3.4 & 0.12 \\
\hline
\end{tabular}

\section{References}

1. Dinh, X.T.; Cassou, E.; Cao, B.T. An Overview of Agricultural Pollution in Vietnam: The Livestock Sector; World Bank Group: Washington, DC, USA, 2017.

2. General Statistic Office of Vietnam. Statistical Yearbook of Vietnam 2016; Statistical Publishing House: Hanoi, Vietnam, 2017; ISBN 978-604-75-0553-1.

3. Garnett, T. Livestock-related greenhouse gas emissions: Impacts and options for policy makers. Environ. Sci. Policy 2009, 12, 491-503. [CrossRef]

4. Bouwman, A.F.; Lee, D.S.; Asman, W.A.H.; Dentener, F.J.; Hoek, K.W.V.D.; Olivier, J.G.J. A global high-resolution emission inventory for ammonia. Glob. Biogeochem. Cycles 1997, 11, 561-587. [CrossRef]

5. Cassou, E.; Jaffee, S.M.; Ru, J. The Challenge of Agricultural Pollution: Evidence from China, Vietnam and the Philippines; Directions in Development; World Bank: Washington, DC, USA, 2017; ISBN 978-1-4648-1202-6.

6. Gu, B.; Sutton, M.A.; Chang, S.X.; Ge, Y.; Chang, J. Agricultural ammonia emissions contribute to China's urban air pollution. Front. Ecol. Environ. 2014, 12, 265-266. [CrossRef]

7. Fangmeier, A.; Hadwiger-Fangmeier, A.; Van der Eerden, L.; Jäger, H.-J. Effects of atmospheric ammonia on vegetation-A review. Environ. Pollut. 1994, 86, 43-82. [CrossRef]

8. Wilkes, A.; Reisinger, A.; Wollenberg, E.; Van Dijk, S. Measurement, Reporting and Verification of Livestock GHG Emissions by Developing Countries in the UNFCCC: Current Practices and Opportunities for Improvement; CGIAR Research Program on Climate Change, Agriculture and Food Security (CCAFS) and Global Research Alliance for Agricultural Greenhouse Gases (GRA): Wageningen, The Netherlands, 2017.

9. Ministry of Natural Resources and Environment. Greenhouse Gas Inventory of Vietnam 2010. Presented at UN Climate Conference for the United Nations Framework Convention on Climate Change, Lima, Peru, 1-12 December 2014.

10. Yamaji, K.; Ohara, T.; Akimoto, H. A country-specific, high-resolution emission inventory for methane from livestock in Asia in 2000. Atmos. Environ. 2003, 37, 4393-4406. [CrossRef]

11. Yamaji, K.; Ohara, T.; Akimoto, $\mathrm{H}$. Regional-specific emission inventory for $\mathrm{NH}_{3}, \mathrm{~N}_{2} \mathrm{O}$, and $\mathrm{CH}_{4}$ via animal farming in South, Southeast, and East Asia. Atmos. Environ. 2004, 38, 7111-7121. [CrossRef]

12. Kurokawa, J.; Ohara, T.; Morikawa, T.; Hanayama, S.; Janssens-Maenhout, G.; Fukui, T.; Kawashima, K.; Akimoto, H. Emissions of air pollutants and greenhouse gases over Asian regions during 2000-2008: Regional Emission inventory in ASia (REAS) version 2. Atmos. Chem. Phys. 2013, 13, 11019-11058. [CrossRef]

13. Ramírez-Restrepo, C.A.; Van Tien, D.; Le Duc, N.; Herrero, M.; Le Dinh, P.; Van, D.D.; Le Thi Hoa, S.; Chi, C.V.; Solano-Patiño, C.; Lerner, A.M.; et al. Estimation of methane emissions from local and crossbreed beef cattle in Daklak province of Vietnam. Asian Australas. J. Anim. Sci. 2017, 30, 1054-1060. [CrossRef] [PubMed]

14. Lê, Đ.N.; Đinh, V.D.; Searchinger, T.D.; Lê, Đ.P. Current situation and scenarios for reducing enteric methane emission from extensive beef cattle production system of smallholders in Quang Ngai province, Vietnam. Can Tho Univ. J. Sci. 2016, 46b, 1-7. [CrossRef] 
15. Hoang, A.L.; Dang, T.X.H.; Dinh, M.C. Emission Inventory for $\mathrm{NH}_{3}, \mathrm{~N}_{2} \mathrm{O}$, and $\mathrm{CH}_{4}$ of Animal Husbandry Activities: A case in Tho Vinh Commune, Kim Dong District, Hung Yen Province. J. Sci. Earth Environ. Sci. 2017, 33, 117-126.

16. IPCC. 2006 IPCC Guidelines for National Greenhouse Gas Inventories; Institute for Global Environmental Strategies (IGES): Hayama, Japan, 2006; Volume 4.

17. Shrestha, R.M.; Nguyen Thi, K.O.; Shrestha, R.P.; Rupakheti, M.; Rajbhandari, S.; Permadi, D.A.; Kanabkaew, T.; Iyngararasan, M. Atmospheric Brown Clouds (ABC) Emission Inventory Manual; United Nations Environment Programme: Nairobi, Kenya, 2013; ISBN 978-92-807-3325-9.

18. General Statistic Office of Vietnam. Statistical Yearbook of Vietnam 2015; Statistical Publishing House: Hanoi, Vietnam, 2016; ISBN 978-604-75-0364-3.

19. General Statistics Office of Vietnam. Statistical Yearbook of Vietnam 2005; Statistical Publishing House: Hanoi, Vietnam, 2006.

20. Vietnam Livestock Production. Available online: http://channuoivietnam.com/thong-ke-chan-nuoi/ (accessed on 11 September 2018).

21. Prime Minister. Decision 124/QD-TTg on Approval of National Agriculture Development Plan until 2020 with Vision to 2030. 2012. Available online: https://www.ecolex.org/details/legislation/decision-no124qd-ttg-approving-the-master-plan-for-agricultural-production-development-through-2020-with-avision-toward-2030-lex-faoc112552/ (assessed on 11 September 2018).

22. Bui, H.D. Production and Quality of Industrial Chicken Manure before and after Compositing. Vietnam. Agric. Sci. J. 2009, 7, 245-252.

23. Vu, T.K.V.; Tran, M.T.; Dang, T.T.S. A survey of manure management on pig farms in Northern Vietnam. Livest. Sci. 2007, 112, 288-297. [CrossRef]

24. Vu, T.T.H.; Vu, Q.C.; Nguyen, T.H.C.; Le, V.C. Results of study on current status and solutions for environmental management in livestock farming in household and small scale farm in the North of Vietnam. J. Water Resour. Sci. Technol. 2013, 18, 41-47.

25. Le, D.N.; Dinh, V.D.; Le, D.P.; Le, V.T.; Vu, C.C.; Le, T.H.S.; Ramírez-Restrepo, C.A. Study on enteric methane emission from smallholder semi-intensive beef cattle production system in the Red River Delta: A case study in Dong Anh District, Hanoi. Sci. Technol. J. Agric. Dev. 2015, 7, 70-79.

26. Lê, Đ.P.; Lê, Đ.N. Scenarios for Reducing Enteric Methane Emission from Small Scale Dairy Production Farms in Ba Vi, Ha Noi. J. Sci. Dev. 2015, 13, 543-550.

27. IPCC. Climate Change 2013: The Physical Science Basis. Contribution of Working Group I to the Fifth Assessment Report of the Intergovernmental Panel on Climate Change; Cambridge University Press: Cambridge, UK; New York, NY, USA, 2013; p. 1535.

28. Vu, T.K.V. Report on Assessment of Climate Change Impact to Livestock Farming and Disease Prevention, Proposed Adaptation Measures; National Institute of Animal Sciences: Hanoi, Vietnam, 2013.

29. Monteny, G.-J.; Bannink, A.; Chadwick, D. Greenhouse gas abatement strategies for animal husbandry. Agric. Ecosyst. Environ. 2006, 112, 163-170. [CrossRef]

30. Prime Minister. Approval of Plan for GHG Emissions Reduction in Agriculture. 2011; Volume 3119/QĐ-BNN-KHCN. Available online: https://www.google.com/url?sa=t\&rct=j\&q=\&esrc=s\& source=web\&cd=1\&ved=2ahUKEwjCr5a6w5veAhXEtYsKHSp2BRgQFjAAegQIABAC\&url=https\%3A\% 2F\%2Ftheredddesk.org\%2Fsites\%2Fdefault\%2Ffiles\%2F3119-qd-bnn-khcn_2.pdf\&usg=AOvVaw2jO-taZeRBiRle1112IiX (assessed on 11 September 2018).

31. Thien Thu, C.T.; Cuong, P.H.; Hang, L.T.; Chao, N.V.; Anh, L.X.; Trach, N.X.; Sommer, S.G. Manure management practices on biogas and non-biogas pig farms in developing countries-Using livestock farms in Vietnam as an example. J. Clean. Prod. 2012, 27, 64-71. [CrossRef]

32. Nugrahaeningtyas, E.; Baek, C.-Y.; Jeon, J.-H.; Jo, H.-J.; Park, K.-H. Greenhouse Gas Emission Intensities for the Livestock Sector in Indonesia, Based on the National Specific Data. Sustainability 2018, 10, 1912. [CrossRef]

(C) 2018 by the authors. Licensee MDPI, Basel, Switzerland. This article is an open access article distributed under the terms and conditions of the Creative Commons Attribution (CC BY) license (http:/ / creativecommons.org/licenses/by/4.0/). 